\title{
Non-viral systemic delivery of siRNA or antisense oligonucleotides targeted to Jun N-terminal kinase 1 prevents cellular hypoxic damage
}

\author{
Seema Betigeri • Min Zhang • Olga Garbuzenko • \\ Tamara Minko
}

Published online: 14 December 2010

(C) The Author(s) 2010. This article is published with open access at Springerlink.com

\begin{abstract}
Many pathological conditions and environmental impacts lead to the development of severe tissue hypoxia that aggravates the primary disorder, provokes cell death, and limits the patient's recovery. We hypothesized that suppression of Jun N-terminal kinase 1 (JNK1) will limit tissue damage induced by severe hypoxia. To test the hypothesis, antisense oligonucleotides (ASO) or small interfering RNA (siRNA) targeted to JNK1 mRNA were incorporated or complexed with neutral or cationic liposomes, respectively, and administered systemically to mice prior to hypoxia exposure. The animals were placed in a special chamber ventilated with room air (normoxia) or a gas mixture containing $6 \% \mathrm{O}_{2}$ and $94 \% \mathrm{~N}_{2}$ (hypoxia). Liposomes, ASO, and siRNA were found to accumulate in the lungs, kidney, spleen, and heart. Only trace amounts of liposomes and their payloads (ASO and siRNA) were found in the brain. The down regulation of JNK1 protein limited activation of cell death signal, apoptotic, and necrotic tissue damage under hypoxic conditions. Consequently, we were able to verify our hypothesis and provide proof of concept of a unique approach to the prevention of cellular hypoxic damage by the suppression of JNK1 signaling pathways after the efficient delivery of ASO or siRNA.
\end{abstract}

Keywords Liposomal delivery of nucleic acids $\cdot$ Hypoxia . Apoptosis and necrosis · Body distribution of siRNA and antisense oligonucleotides

\footnotetext{
S. Betigeri $\cdot$ M. Zhang $\cdot$ O. Garbuzenko $\cdot$ T. Minko $(\bowtie)$

Department of Pharmaceutics, Ernest Mario School of Pharmacy, Rutgers, The State University of New Jersey,

160 Frelinghuysen Road,

Piscataway, NJ 08854-8020, USA

e-mail: minko@rci.rutgers.edu
}

\section{Introduction}

Many environmental factors as well as endogenous disturbances in blood oxygenation and circulation are often associated with limitations in the oxygen delivery to tissues and cells. Severe deprivation in adequate oxygen supply may cause marked tissue damage and finally lead to hypoxic cell death (Busl and Greer 2010; Goni-de-Cerio et al. 2007; Hossain 2008; Minko et al. 2002; Minko et al. 2005; Soleymanlou et al. 2007; Vacotto et al. 2008). Moreover, reoxygenation - a restoration of oxygen supply to the formerly hypoxic tissues as a result of the treatment, compensatory reactions of an organism, or ending of exogenous hypoxic conditions may lead even to more pronounced tissue damage (Dhar-Mascareno et al. 2005; Freiberg et al. 2006; Hung and Burton 2006; Kim et al. 2007; Ricci et al. 2009; Yajima et al. 2009). Despite substantial differences in the physiological conditions during hypoxia and reoxygenation, the main mechanisms of tissue damage under both settings are quite similar. The major mechanisms include disturbances in cellular metabolism, mitochondrial dysfunctions, disturbances in acid-base homeostasis, oxidative stress damage by active oxygen and nitrogen species, and apoptotic and necrotic cell death (Blokhina and Fagerstedt 2010; Boning et al. 2008; Cho et al. 2007b; Gonchar and Mankovskaya 2009; Kim et al. 2004; Kim and Park 2003; Kothari et al. 2003; Minko et al. 2002; Minko et al. 2005; Murray et al. 2003; Portugal-Cohen and Kohen 2009; Surova et al. 2009; Vacotto et al. 2008; Yajima et al. 2009). Consequently, the suppression of the above-mentioned mechanisms of hypoxic cellular damage can potentially be used in effective therapy of many diseases associated with hypoxia and/or reoxygenation and to increase the resistance to damaging environmental factors. Several approaches have been recently proposed including preliminary adaptation to 
hypoxia, stress, and other environmental factors (Boning et al. 2008; Corbucci et al. 2005; Gonchar and Mankovskaya 2009; Meerson et al. 1994; Millet et al. 2010; Ostadal and Kolar 2007; Zhao et al. 2009) as well as many pharmacological methods (Betigeri et al. 2006; Carlsson et al. 2009; Cho et al. 2007a; Danielyan et al. 2006; Lecour et al. 2006; Minciu Macrea et al. 2010; Minko et al. 2002; Minko et al. 2005; Myllyharju 2008; Nagel et al. 2010; Surova et al. 2009; Wenger et al. 2009; Zhu et al. 2008).

Hypoxia inducible factor one alpha (HIF1A) protein is a key initiator of cell death signal under hypoxic conditions (Hellwig-Burgel et al. 2005). We investigated the role of this protein as a possible target for the remediation of hypoxic cellular damage and found that HIF1A plays a bimodal role during hypoxia (Wang and Minko 2004; Wang et al. 2004; Wang et al. 2008). On the one hand, activation of HIF1A during hypoxia initiates cell death signal inducing apoptosis (programmed cell death or cellular suicide) and necrosis (pathological cell death). On the other hand, overexpression of HIF1A boosts the power of antihypoxic systems that increase cellular resistance to hypoxia.

Recently, we identified Jun N-terminal kinase 1 (JNK1), another major player in the activation of apoptosis signaling pathways and hypoxic damage from the mitogen-activated protein kinas (MAPK) family of proteins, as a prospective target for pharmacological prevention of cellular damage during severe hypoxia (Betigeri et al. 2006). It has been shown that JNK1 as a stress-activated protein kinase can be induced by inflammatory cytokines, bacterial endotoxin, osmotic shock, UV radiation, and hypoxia (Bennett et al. 2001; Chihab et al. 1998; Zhou et al. 2004). Analysis of literature data (Bennett et al. 2001; Derijard et al. 1994; Karin 1995) showed that cellular hypoxic damage can be induced by the pathway presented in Fig. 1. Induction of JNK by hypoxia mediates phosphorylation of activating transcriptional factor-2 (ATF2) and c-Jun bound to the $c$ Jun promoter and stimulates their transcriptional activities leading to $c$-Jun activation. The newly synthesized c-Jun protein combines with c-Fos protein to form stable transcriptional factor activator protein-1 (AP1) heterodimers. The formation of AP1 is a key step following the induction of central cell death signal leading to the activation of caspasedependent apoptosis signal pathways and finally causing cell death. It was found that c-Jun N-terminal kinase 1 (JNK1, SAPK1 and MAPK8) plays a central role in the development of cellular damage under hypoxia, hypoxia/reoxygenation, and ischemia/reperfusion conditions (Crenesse et al. 2003; Garay et al. 2000; Hreniuk et al. 2001). The in vitro data previously obtained in our laboratory showed that the suppression of JNK1 by antisense oligonucleotides (ASO) or small interfering RNA (siRNA) targeted to JNK1 mRNA substantially limited cellular mortality after severe hypoxia (Betigeri et al. 2006). The present study is a logical

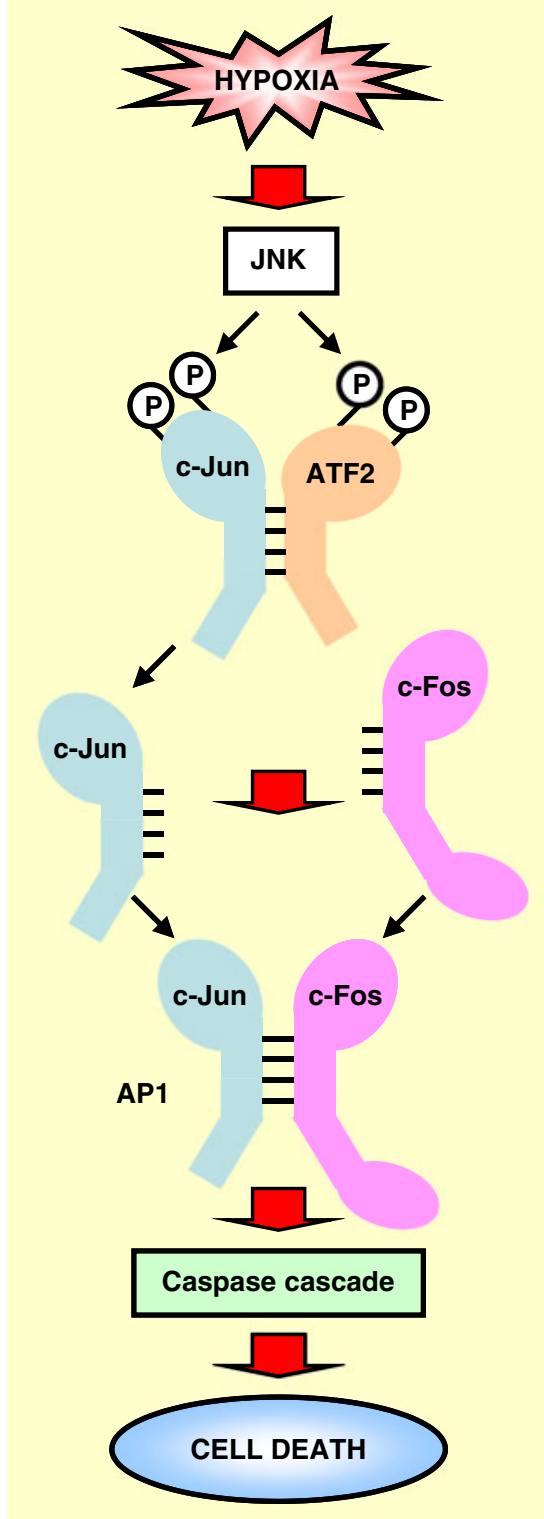

Fig. 1 Schema of apoptosis induction by hypoxia. Activation of Jun Nterminal kinase $(J N K)$ by hypoxia mediates phosphorylation of activating transcriptional factor-2 (ATF2) and c-Jun and stimulates their transcriptional activities. The newly synthesized c-Jun protein combines with c-Fos protein to form stable transcriptional factor activator protein-1 $(A P 1)$ heterodimers. The formation of AP1 activates caspase-dependent apoptosis signal and finally induces cell death

continuation of our previous work and is aimed at in vivo testing of this approach.

\section{Material and methods}

Liposomal compositions of siRNA and ASO

Negatively charged siRNA was delivered by cationic liposomes (N-[1-(2,3-Dioleoyloxy) propyl]- $N, N, N$-trimethylam- 
monium methylsulfate, DOTAP, Avanti Polar Lipids, Alabaster, AL). ASO targeted to JNK1 mRNA (5'-CTC TCT GTA GGC CCG CTT GG-3') (Garay et al. 2000) and ASO labeled with fluorescein isothiocyanate (FITC) were synthesized by Oligos Etc. (Wilsonville, OR). The DNA backbone of all bases in oligonucleotides was P-ethoxy modified in order to eliminate electrical charge and increase incorporation efficacy into "neutral" PEGylated liposomes. Liposomes were prepared as described previously (Garbuzenko et al. 2009; Garbuzenko et al. 2010; Pakunlu et al. 2006). Briefly, to prepare PEGylated liposomes, egg phosphotidyl choline, cholesterol, and DSPEPEG (1,2-distearoyl-sn-glycero-3-phosphoetanolamine- $N$ aminopolyethylene glycol- $\mathrm{M}_{\mathrm{w}} \sim 2,000$ ammonium salt) were dissolved in $4.0 \mathrm{ml}$ of chloroform at 1.85:1:0.15 molar ratio, respectively (all compounds were obtained from Avanti Polar Lipids, Alabaster, AL). The clear lipid solution was evaporated at $25^{\circ} \mathrm{C}$ under reduced pressure. A thin layer was formed and rehydrated using $2.0 \mathrm{ml}$ of $0.3 \mathrm{M}$ sodium citrate buffer $(\mathrm{pH}=4.0)$. ASO was loaded into liposomes by dissolving in rehydration buffer at concentration $0.5 \mathrm{mM}$. The lipid mixture was sonicated continuously for $3.0 \mathrm{~h}$ to obtain stealth liposomes. Liposomes were extruded gradually through 100 and $200 \mathrm{~nm}$ polycarbonate membranes at room temperature using an extruder device from Northern Lipids, Inc. (Vancuver, BC, Canada). Liposomes were separated from non-encapsulated ASO by dialysis against 100 volumes of $0.9 \% \mathrm{NaCl}$. The encapsulation efficacy of ASO was $\sim 50$ $60 \%$, respectively. The final phospholipids concentration was $10 \mathrm{mg} / \mathrm{ml}$. Mean diameter of "neutral" liposomes was 100 $140 \mathrm{~nm}$. siRNA targeted to exon 1 JNK1 mRNA (sense sequence-3'-GGA GCU CAA GGA AUA GUA UTT-5') was selected based on the results of our previous studies (Betigeri et al. 2006) and synthesized according to our design by Ambion (Austin, TX). A siGLO Green 6-FAM transfection indicator was purchased from Dharmacon, Inc. (Chicago, IL). siRNA possess negative charges requiring positively charged (cationic) liposomes to form stable complexes. Cationic liposomes were prepared from positively charged DOTAP at concentration $5 \mathrm{mg} / \mathrm{mL}$ using thin layer procedure as previously described (Betigeri et al. 2006; Garbuzenko et al. 2009), followed by extrusion through $100 \mathrm{~nm}$ polycarbonate membrane. The siRNA was dissolved in RNase free water at a concentration of $400 \mu \mathrm{M}$. To this solution, appropriate volume of DOTAP $(5 \mathrm{mg} / \mathrm{mL})$ was added, mixed by pipette and incubated for $30 \mathrm{~min}$ at room temperature. The molar ratio of siRNA/DOTAP was $\sim$ 1:100. Resulting siRNA-cationic liposome complex was used in the studies. siGLO Green was dissolved in RNAse free solution to the final concentration of $200 \mu \mathrm{M}$. DOTAP liposomes were mixed with siGLO in the ration $6: 1 v / v$ and incubated at room temperature for $15 \mathrm{~min}$ before use. Mean DOTAP/siGLO complex size was around $500 \mathrm{~nm}$. Aliquots of each liposomal formulation were labeled with near infrared fluorescent dye Cy5.5 Mono NHS Ester (GE Healthcare, Amersham, UK). A fluorescent dye was dissolved together with lipids in chloroform. Approximate excitation/emission maxima of all fluorescent substances used in the study are: 675/694 nm (Cy5.5); 520/594 nm (siGLO Green, siRNA labeled with 6-FAM dye); 494/518 nm (FITC).

\section{Liposome size and zeta potential}

Particle size was measured by dynamic light scattering using 90 Plus Particle Sizer Analyzer (Brookhaven Instruments Corp., New York, NY). Aliquot of $40 \mu \mathrm{L}$ of each sample was diluted in $2 \mathrm{~mL}$ of saline. Zeta potential was measured on PALS Zeta Potential Analyzer (Brookhaven Instruments Corp, New York, NY). Samples were taken as is and their volume was $1.5 \mathrm{~mL}$. All measurements were carried out at room temperature. Each parameter was measured in triplicate, and average values were calculated.

\section{Cell line}

The human embryonic kidney 293 cells were obtained from American Type of Tissue Culture (Manassas, VA). Cells were cultured in Dulbecco's modified Eagle's medium (GIBCO Inc., Cincinnati, $\mathrm{OH}$ ) supplemented with $10 \%$ fetal bovine serum (Fisher Chemicals, Fairlawn, NJ). All experiments were performed on cells in the exponential growth phase.

Cellular uptake and localization of liposomes, ASO and siRNA

Cellular internalization of liposomes, ASO and siRNA were monitored by fluorescence microscopy. Four series of the experiments were carried out: (1) "neutral" liposomes labeled with Cy5.5 (red fluorescence); (2) cationic liposomes labeled with Cy5.5 (red fluorescence); (3) ASO labeled with FITC (green fluorescence) delivered by "neutral" liposomes; and (4) siRNA labeled with 6-FAM (siGLO Green, green fluorescence) delivered by cationic liposomes. Cells were separately incubated for $24 \mathrm{~h}$ at $37^{\circ} \mathrm{C}$ with each liposomal formulation.

Animal model of hypoxia exposure

Experiments were performed on healthy 6-8 weeks old SKH1-hr hairless mice (25-35 g) obtained from Charles River Laboratories (Wilmington, MA). Veterinary care followed the guidelines described in the guide for the care and use of laboratory animals as well as the requirements established by the animal protocol approved by the Rutgers Institutional Animal Care and Use Committee. All mice were contained in micro-isolated cages under pathogen free 
conditions at room temperature with humidity of $40 \pm 15 \%$ and light/dark cycle on $12 \mathrm{~h}$ per day in the animal maintenance facility. Normobaric hypoxia was created in a $300 \times 350 \times 600 \mathrm{~mm}$ Plexiglas chamber specifically designed for this project by Billups-Rothenberg, Inc. (Del Mar, CA). Hypoxia was induced by subjecting the chamber to a constant flow (15-20 $\mathrm{l} / \mathrm{min})$ of hypoxic gas mixture containing $6 \%$ oxygen and $94 \%$ nitrogen. The oxygen concentration in the chamber was continuously monitored using an oxygen analyzer (Vascular Technology, Inc., Nashua, NH). A heating pad was placed inside the Plexiglass chamber to maintain the body temperature of the mice. All animals were placed in the chamber for $2 \mathrm{~h}$. Prior to exposure, mice were pretreated with $100 \mu \mathrm{L}$ of different formulations by intravenous injection. Mice were randomized into six experimental groups: (1) normoxia (room air, 21\% $\mathrm{O}_{2}$ ) following injection of saline; (2) hypoxia $\left(6 \% \mathrm{O}_{2}\right)$ following injection of saline; (3) hypoxia $\left(6 \% \mathrm{O}_{2}\right)$ following injection of neutral liposomes; (4) hypoxia (6\% $\mathrm{O}_{2}$ ) following injection of cationic liposomes; (5) hypoxia $\left(6 \% \mathrm{O}_{2}\right)$ following injection of neutral liposomes with ASO targeted to JNK1 mRNA; (6) hypoxia $\left(6 \% \mathrm{O}_{2}\right)$ following injection of cationic liposomes with siRNA targeted to JNK1 mRNA. The doses of ASO and siRNA were 13 nmoles per mouse ( 80 and $173 \mu \mathrm{g}$ ASO and siRNA, respectively). After the treatment, all mice were anesthetized with isoflurane and euthanized. The organs (lungs, heart, liver, kidney, spleen, and brain) were excised and used for the evaluation of body distribution of liposomes and their payloads (siRNA and ASO), study of lactic acid, apoptosis, gene and protein expression and histopathological analysis.

\section{Content of liposomes in different organs}

The distribution of fluorescent-labeled "neutral" and cationic liposomes and their payloads (ASO and siRNA) was examined in mouse lungs, heart, liver, spleen, and kidneys. The organs were excised, rinsed in saline, and fluorescence was registered by IVIS imaging system (Xenogen Corporation, Alameda, CA). Visible light and fluorescence images were taken and overlaid. The intensity of fluorescence was represented on composite light/fluorescent images by different colors with blue color reflecting the lowest fluorescence intensity and red color - the highest intensity. Images of each organ were then scanned and total fluorescence intensity was calculated by a special computer program originally developed for our laboratory by Dr. V. P. Pozharov as previously described (Garbuzenko et al. 2009; Garbuzenko et al. 2010). Preliminary experiments showed a strong linear correlation between the total amount of labeled substance accumulated in the organ and calculated total fluorescence intensity. The fluorescence was expressed in arbitrary units with 1 unit represented approximately $2 \times 10^{10}$ photons $/ \mathrm{s} / \mathrm{sr} / \mathrm{cm}^{2}$. The method allows a quantitative comparison of the concentration of the same fluorescent dye between different series of the experiments. The mass of all organs was measured. No statistical differences were found in the mass of the same organ between all experimental groups of animals. The fluorescence intensity was normalized for organ weight.

Lactic acid and protein concentration

Approximately $30-40 \mathrm{mg}$ of tissues was weighed, lysed in Ripa buffer (Santa Cruz Biotechnologies, Inc., Santa Cruz, CA) and homogenized using Ultra Turrax T-25 basic homogenizer (IKA Works, Wilmington, NC). To confirm the existence of cellular hypoxia, the concentration of lactic acid in tissue homogenates was measured by an enzymatic assay kit (Sigma, St. Louis, MO) and was expressed per g of protein determined using the BCA protein assay kit (Pierce, Rockford, IL).

\section{Gene expression}

Quantitative reverse transcriptase-polymerase chain reaction (RT-PCR) was used for the analysis of genes encoding JNK1, caspase 9, and $\beta$-actin as previously described (Betigeri et al. 2006; Dharap et al. 2005; Minko et al. 1999; Pakunlu et al. 2003; Pakunlu et al. 2004; Wang et al. 2004) RNA was isolated using an RNeasy kit (Qiagen, Valencia, CA). The following pair of primers were used: JNK1, 5'TTGGAACACCATGTCCTGAA-3' (sense) and 5'-ATG TAC GGG TGT TGG AGA GC-3' (antisense); caspase 9, 5'-TGA CTG CCA AGA AAA TGG TG-3' (sense) and 5'CAG CTG GTC CCA TTG AAG AT- $3^{\prime}$ (antisense); and $\beta$ actin, 5'-GAC AAC GGC TCC GGC ATG TGC A $3^{\prime}$ (sense) and 5'-TGA GGA TGC CTC TCT TGC TCT G-3' (antisense). Gene expression was calculated as the ratio of analyzed RT-PCR product to the internal standard ( $\beta$-actin).

\section{Protein expression}

To confirm RT-PCR data the expression of JNK1 protein and caspase 9 were measured by two methods: Western immunoblotting analysis and immunohistochemistry. The identification of the above proteins was conducted by Western immunoblotting analysis and processed using scanning densitometry to quantify the expressed proteins. To this end, approximately $30-40 \mathrm{mg}$ of the tissue from each organ was weighed, lysed in Ripa buffer (Santa Cruz Biotechnologies, Inc., Santa Cruz, CA), and homogenized using Ultra Turrax T-25 basic homogenizer (IKA Works, Wilmington, NC). Following incubation on ice for $45 \mathrm{~min}$, the tissues were centrifuged at $10,000 \times g$ for $10 \mathrm{~min}$. Protein content in the supernatant was determined using the BCA Protein Assay Kit (Pierce, Rockford, IL) and $40 \mu \mathrm{g}$ of 

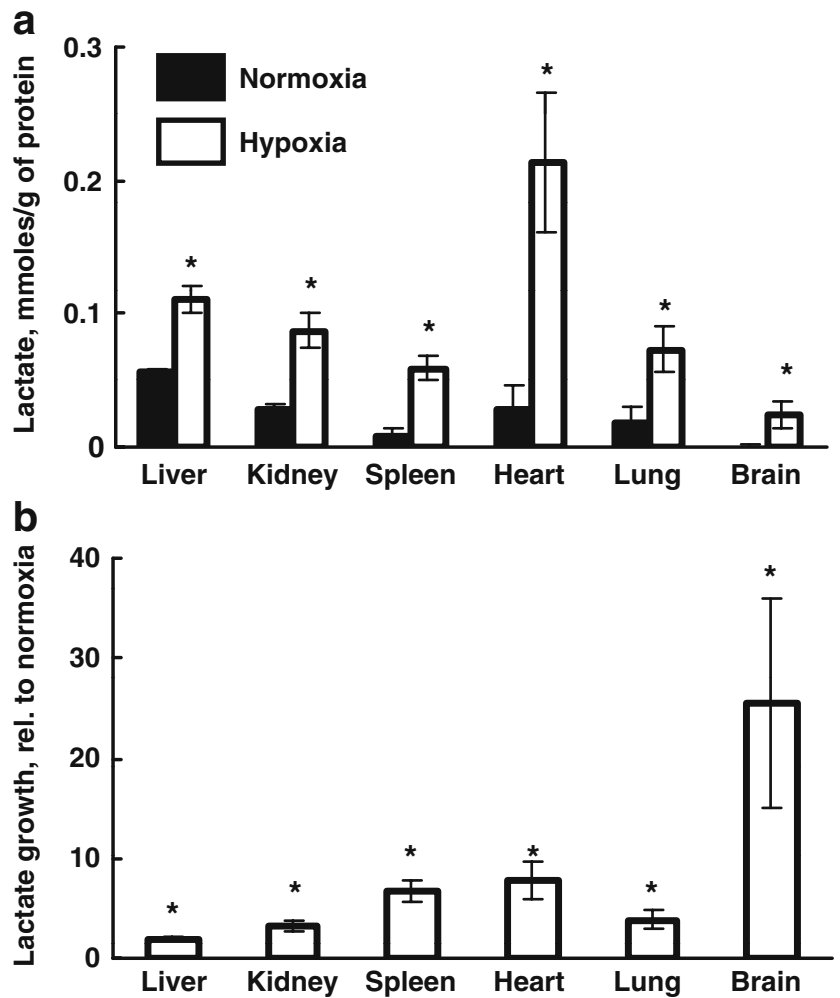

Fig. 2 Accumulation of lactic acid in different organs under hypoxia. a Absolute values. b Lactic acid growth under hypoxia relative to normoxia values. Hypoxia was induced in mice by the inhalation of gas mixture containing $6 \% \mathrm{O}_{2}$ for $2 \mathrm{~h}$. Means $\pm \mathrm{SD}$ are shown. ${ }^{*} P<$ 0.05 when compared with normoxia

protein was run on a $15 \%$ sodium dodecyl sulphate (SDS) polyacrylamide gel immersed in Tris/Glycine/SDS buffer (BioRad, Hercules, CA) for $90 \mathrm{~min}$ at $70 \mathrm{~V}$. Proteins were transferred to an Immobilon-P nitrocellulose membrane (Millipore, Bedford, MA) in a Tris/Glycine buffer (BioRad, Hercules, CA) for $90 \mathrm{~min}$ at $100 \mathrm{~V}$. The membrane was blocked in non-fat milk for $2 \mathrm{~h}$ at room temperature on a rotating shaker to prevent non-specific binding, washed and incubated overnight with anti-JNK1 mouse primary antibody (1:2,000 dilution, Cell Signaling Technology, Inc., Beverly, MA), anti-caspase 9 rabbit primary antibody $(1: 2,000$ dilution, Stress Gen Biotechnologies, Victoria State, BC Canada) and anti-b-actin mice primary antibody $(1: 2,000$ dilution, Oncogene Research, San Diego, CA) at $4{ }^{\circ} \mathrm{C}$. Following further washing, the membrane was immersed in goat anti-rabbit and goat anti-mouse IgG biotinylated antibodies (1:3,000 and 1:1,000 dilution, respectively, BioRad, Hercules, CA) at room temperature for $1.5 \mathrm{~h}$ on a rotating shaker. Bands were visualized using an alkaline phosphatase color development reagent (BioRad, Hercules, CA). The bands were digitally photographed and scanned using Gel Documentation System 920 (NucleoTech, San Mateo, CA). $\beta$-actin was used as an internal standard to normalize protein expression. Protein expression was calculated as the ratio of mean band density of the analyzed protein to that of the internal standard ( $\beta$-actin). The identification of the JNK1 protein was also made by immunohistochemical staining of paraffin embedded tissue sections. After deparaffinization and rehydration, the slides were stained using $\operatorname{Vector}^{\circledR}$ M.O.M. Immunodetection Kit (Vector Laboratories, Inc., Burlingame, CA). Mouse monoclonal antibody to JNK1 (Cell Signaling Technology, Inc., Beverly, MA, 1:40 dilution) was used as the primary antibody for detection. Biotinylated anti-mouse IgG Reagent (1:250 dilution, Vector Laboratories, Inc., Burlingame, CA) and HSP-Streptavidine Detection System (1:500 dilution, Vector Laboratories, Inc., Burlingame, CA) in combination with $\mathrm{DAB}$ substrate kit for peroxidase were used for visualization. After staining, the slides were analyzed by light microscopy and photographed.

\section{Apoptosis}

Apoptosis was analyzed by measuring the enrichment of histone-associated DNA fragments (mono- and oligonucleosomes) in the cell cytoplasm using anti-histone and anti-DNA antibodies by a cell death detection ELISA Plus kit (Roche, Nutley, NJ) as previously described (Dharap et al. 2005; Pakunlu et al. 2004; Wang et al. 2004).
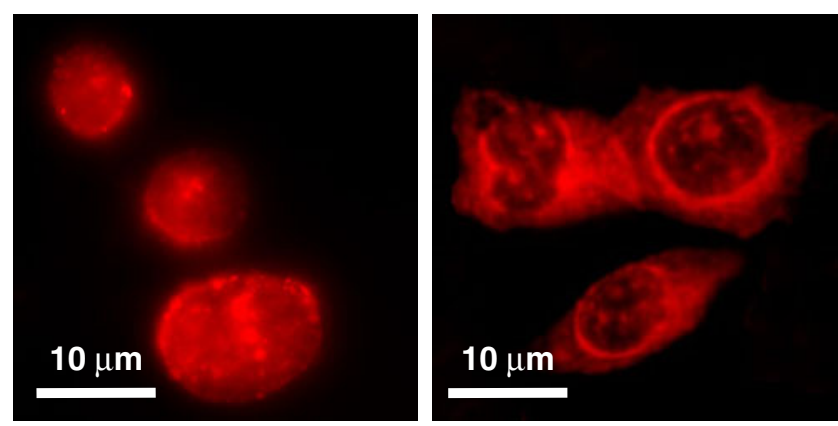

Neutral liposomes-Cy5.5 Cationic liposomes-Cy5.5

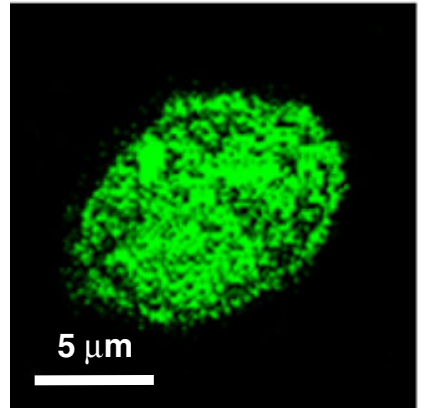

ASO-FITC delivered by neutral liposomes

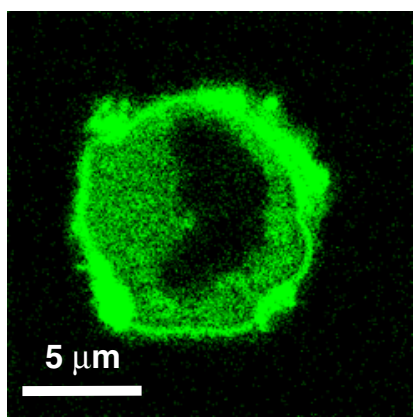

siRNA-FAM delivered by cationic liposomes
Fig. 3 Intracellular localization of neutral and cationic liposomes, antisense oligonucleotides (ASO) and siRNA delivered by neutral and cationic liposomes, respectively. Representative fluorescence images of cells incubated $120 \mathrm{~min}$ with substances indicated. Neutral and cationic liposomes were labeled by Cy5.5 (red), ASO were labeled by FITC (green), siRNA were labeled by FAM (siGLO Green) 
Histopathological examination

After sacrificing animals, the organs were excised and immediately fixed in $10 \%$ phosphate-buffered formalin. Samples were subsequently dehydrated and embedded in Paraplast ${ }^{\circledR}$. Five-micrometer slides were cut and stained with hematoxylin-eosin and analyzed.

\section{Statistical analysis}

Data obtained were analyzed using descriptive statistics, single-factor analysis of variance, and presented as mean values \pm the standard deviation (SD) from four to eight independent measurements in separate experiments. The comparison among groups was performed by the independent sample Student's $t$ tests. The difference between variants is considered significant if $P<0.05$.

\section{Results}

Particle size and zeta potential

Our data showed that the size of all formulations of "neutral" liposomes (empty and with ASO) was 100-140 nm. The average size of empty cationic liposomes and DOTAP/siRNA complexes was 120 and $500 \mathrm{~nm}$, respectively. "Neutral" liposomes had a slight negative charge $(-10 \pm 2 \mathrm{mV})$. DOTAP liposomes had a positive charge $(+25 \pm 4 \mathrm{mV})$. The formation of DOTAP/siRNA complexes decreased the surface charge to $+4 \pm 2 \mathrm{mV}$ likely due to the electrostatic interactions between positively charged lipid and negatively charged siRNA.

\section{Development of tissue hypoxia}

The accumulation of lactic acid in tissues was used as a hallmark of the development of severe tissue hypoxia in different organs of mice during exogenous hypoxia. Data obtained show that the exposure of mice to $6 \% \mathrm{O}_{2}$ in the inspired gas mixture led to a significant increase of the absolute concentration of lactic acid in all studied organs within $2 \mathrm{~h}$ (Fig. 2a). The most dramatic relative increase in the lactic acid concentration in tissues was registered in the brain, heart, spleen, and lungs (Fig. 2b). These data clearly show that the experimental conditions used led to the development of a severe tissue hypoxia in many organs of mice exposed to the hypoxic gas mixture.

\section{Delivery of ASO and siRNA}

Our previous findings showed that naked ASO and siRNA poorly penetrate cellular plasma membrane and therefore require special delivery systems for efficient intracellular uptake (Patil et al. 2008; Wang et al. 2008). Consequently, neutral and cationic phospholipid liposomes were used to deliver neutral P-ethoxy ASO and negatively charged siRNA, respectively. In vitro data obtained in the present study demonstrate that liposomes provide for an effective intracellular delivery of both ASO and siRNA (Fig. 3). Delivered by liposomes ASO were distributed homogenously in the cytoplasm and nucleus of exposed cells, while siRNA was accumulated predominately in the cytoplasm. These data allowed us to use both types of liposomes for systemic delivery of ASO and siRNA in vivo. The analysis of body distribution of liposomes and delivered payload showed that the content of liposomes, ASO and siRNA per gram of wet tissue was highest in the lungs. In contrast, only trace amounts of liposomes and payload were found in the brain. A substantial amount of ASO or siRNA was found in the heart (Fig. 4). Based on the organ content of active components as well as on the degree of tissue hypoxia, we selected the lungs (the highest ASO or siRNA accumulation and moderate

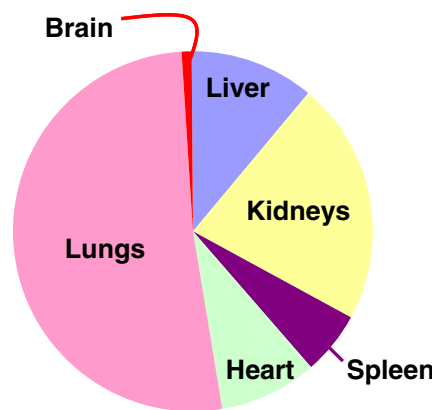

Neutral liposomes

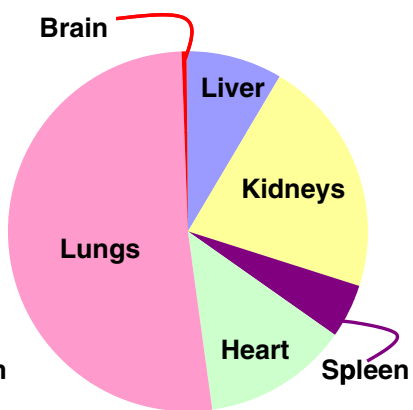

Cationic liposomes
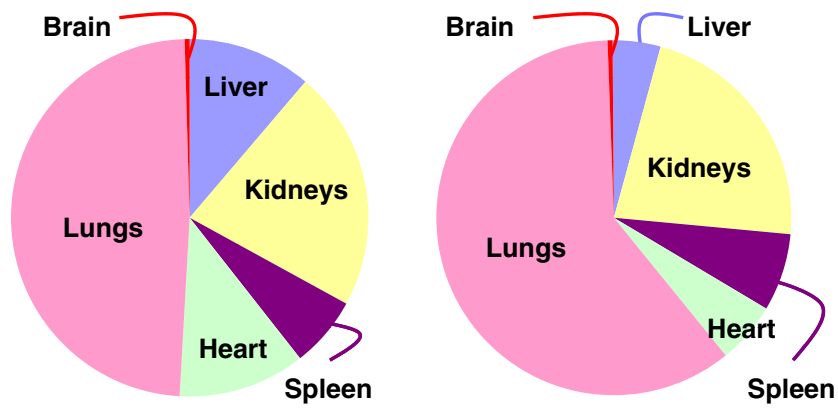

Neutral liposomes-ASO Cationic liposomes-siRNA

Fig. 4 Relative tissue content of empty neutral and cationic liposomes, antisense oligonucleotides (ASO) and small interfering RNA (siRNA) in different organs. Neutral P-ethoxy ASO and negatively charged siRNA were delivered by neutral and cationic liposomes, respectively. Liposomes, ASO and siRNA were labeled with fluorescent dyes and intravenously injected to heirless mice. Two hours after treatment mice were euthanized, organs were excised, fluorescence was registered by IVIS imaging system and normalized per gram of tissue weight in each organ 
hypoxia), heart (moderate hypoxia and moderate ASO or siRNA accumulation) and brain (the highest hypoxia and the lowest ASO or siRNA accumulation) for further detailed study.

\section{Suppression of JNK1 protein}

Suppression of the targeted JNK1 mRNA and protein by ASO or siRNA delivered by liposomes was studied by RTPCR and immunohistochemical protein staining. The results showed that hypoxia led to the significant overexpression of the JNK1 gene and protein (Fig. 5a (bar 2), b for the gene and protein, respectively). Empty neutral or cationic liposomes did not have a significant influence on this overexpression (Fig. 5a (bars 3 and 4), b). Treatment of mice with liposomes containing ASO or siRNA targeted to
JNK1 mRNA led to a substantial decrease in the expression of this gene and protein in the lungs and heart under hypoxic conditions (Fig. 5a (bars 5 and 6), b). In contrast, treatment of mice with liposomes contained JNK1 ASO or siRNA did not influence the expression of either the mRNA or protein in the brain under hypoxic exposure. In general, one can conclude that the efficiency of the suppression of targeted JNK1 mRNA and protein correlated with the organ content of delivered ASO or siRNA.

Inhibition of hypoxic cell damage and death

To examine the hypoxic cellular damage and influence of the suppression of JNK1 on this process, we carried out a histopathological analysis (hematoxylin-eosin stain) and a

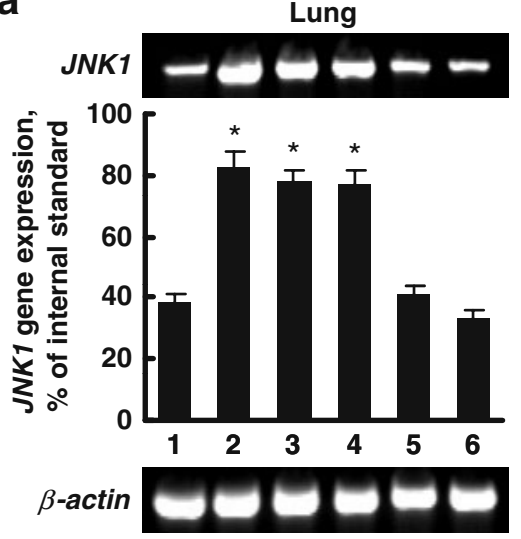

Heart

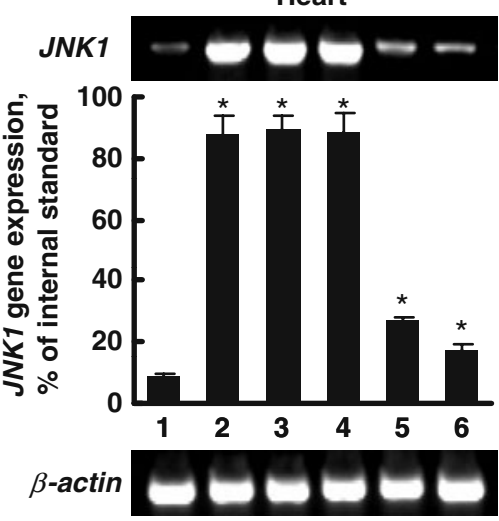

Brain

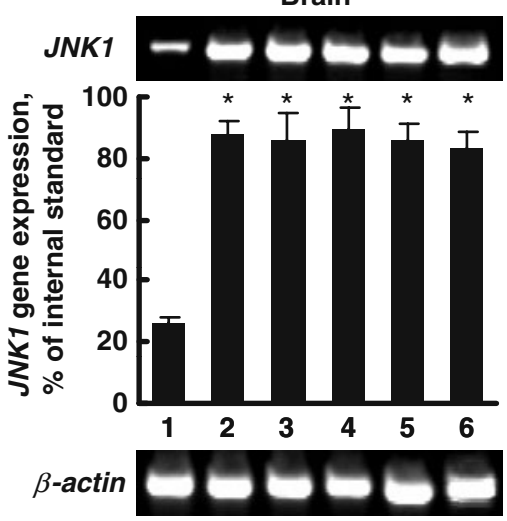

1. Normoxia

3. Hypoxia + neutral liposomes

2. Hypoxia
4. Hypoxia + cationic liposomes
5. Hypoxia + neutral liposomes with JNK1 ASO

6. Hypoxia + cationic liposomes with JNK1 siRNA b

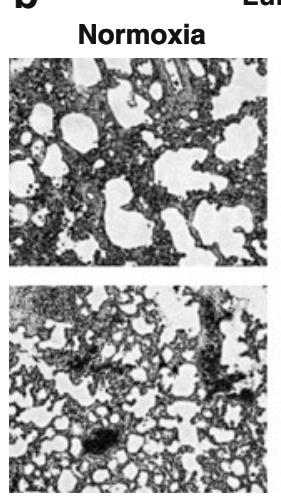

Hypoxia + neutral liposomes with JNK1 ASO
Lung
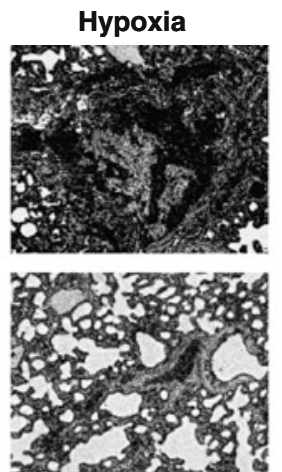

Hypoxia + cationic liposomes with JNK1 siRNA
Heart

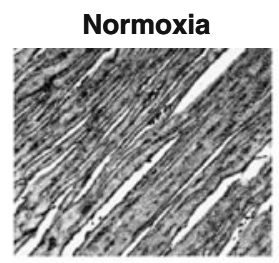

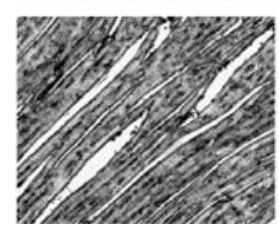

Hypoxia + neutral liposomes with JNK1 ASO
Fig. 5 Expression of JNK1 gene and protein in mouse organs under normoxia and hypoxia. Hypoxia was induced in mice by the inhalation of gas mixture containing $6 \% \mathrm{O}_{2}$ for $2 \mathrm{~h}$. Control mice (normoxia, 1 ) breathed room air $\left(21 \% \mathrm{O}_{2}\right)$ in the same chamber as animals with hypoxia. Mice were treated with saline (normoxia-control, 1; hypoxia, 2) and indicated substances (3-6) immediately before the
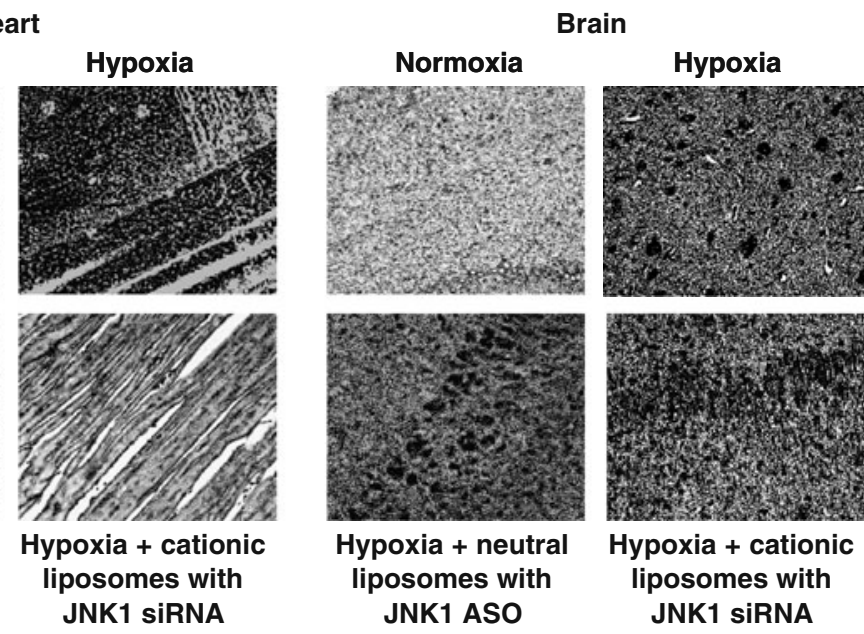

exposure. a Typical gel electrophoresis images of RT-PCR products and average expression of the $J N K 1$ gene. Gene expression was calculated as a ratio of band intensity of $J N K 1$ gene to that of internal standard (b-actin). Means $\pm \mathrm{SD}$ are shown. ${ }^{*} P<0.05$ when compared with control. b Typical images of tissue sections stained with antibody against JNK1 protein. Dark color indicates high protein expression 
a

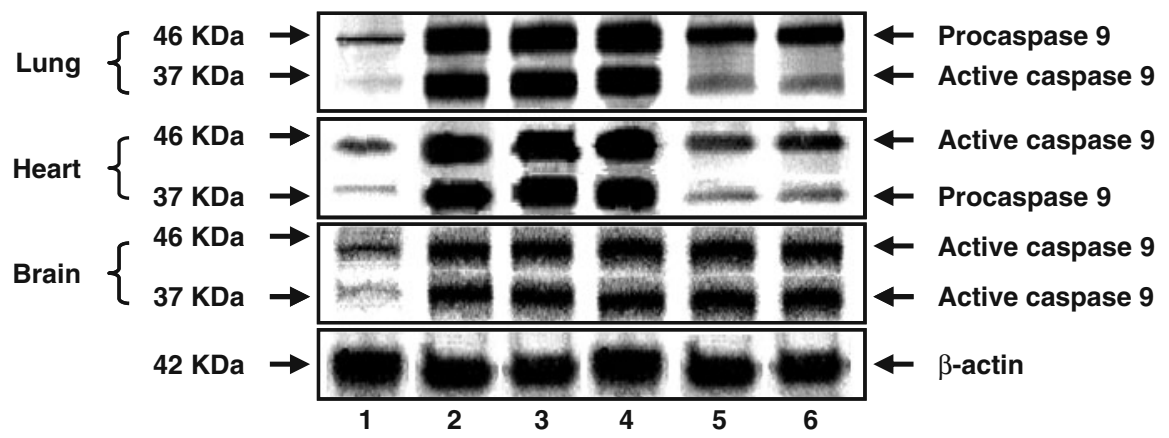

1. Normoxia

2. Hypoxia
3. Hypoxia + neutral liposomes

4. Hypoxia + cationic liposomes
5. Hypoxia + neutral liposomes with JNK1 ASO

6. Hypoxia + cationic liposomes with JNK1 siRNA b

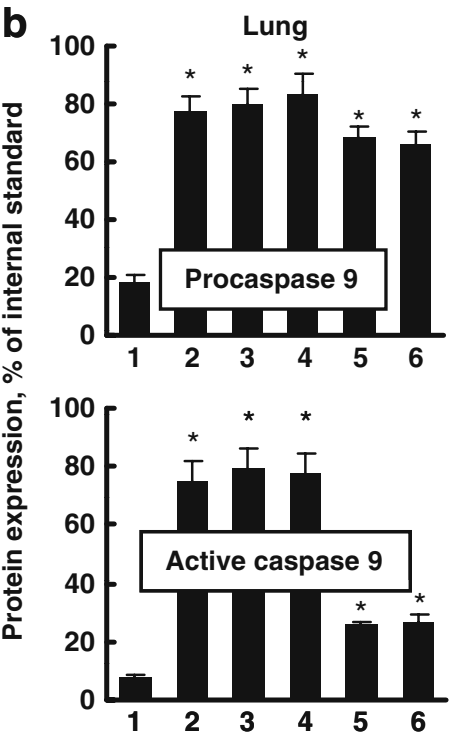

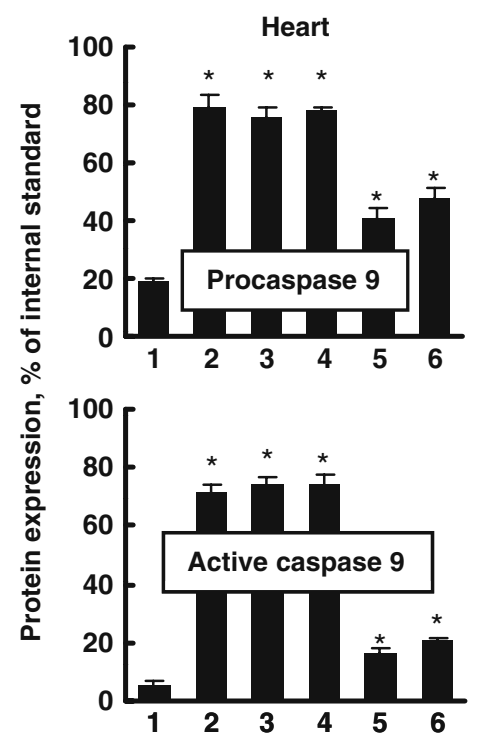

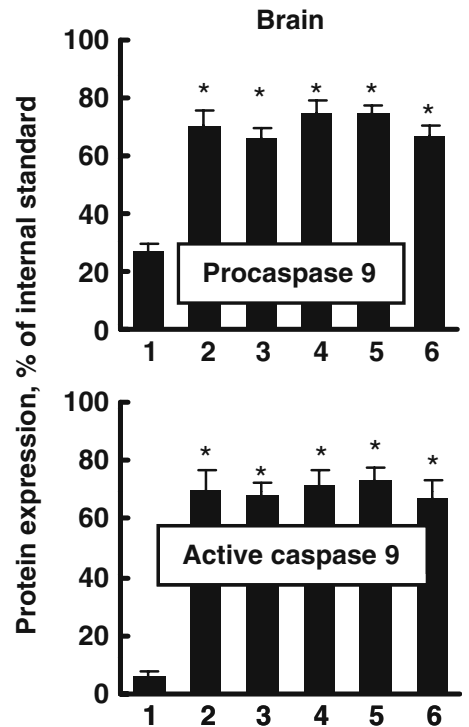

Fig. 6 Expression of caspase 9 in mouse organs under normoxia and hypoxia. Hypoxia was induced in mice by the inhalation of gas mixture containing $6 \% \mathrm{O}_{2}$ for $2 \mathrm{~h}$. Control mice (normoxia, l) breathed room air $\left(21 \% \mathrm{O}_{2}\right)$ in the same chamber as animals with hypoxia. Mice were treated with saline (normoxia-control, 1; hypoxia, 2) and indicated substances (3-6) immediately before the

studied the expression of the main cell death signaling protein - caspase 9 and apoptosis induction in the selected tissues. The data show that hypoxia led to the overexpression of both procaspase and active caspase 9 (compare Fig. 6a (lanes 1 and 2) and b (bars 1 and 2)) in all studied organs. Empty liposomes (neutral and cationic) did not lead to substantial changes in the expression of procaspase and active caspase 9 (Fig. 6a (lanes 3 and 4), b (bars 3 and 4)). Systemic delivery of ASO and siRNA prior to hypoxia limited the activation of this pathway of apoptosis leading to the decrease in the expression of both procaspase and active caspase 9 in the lungs and heart (Fig. 6a (lanes 5 and 6), b (bars 5 and 6)). In contrast, treatment of mice with liposomal ASO and siRNA did not influence the expression of these proteins in the brain under hypoxia. The direct measure- exposure. a Representative images of Western blots of procaspase and active caspase 9 and $\beta$-actin (internal standard) proteins and $\mathbf{b}$ densitometric analysis of bands. Band intensities of pro- and active caspase 9 are expressed as the percentage of the $\beta$-actin band intensity, which was set at $100 \%$. Means \pm SD are shown. ${ }^{*} P<0.05$ when compared with control

ments of apoptosis induction in the tissues showed that hypoxia induced cell death in all studied organs (Fig. 7). In fact, enrichment of histone-associated DNA fragments (mono- and oligo-nucleosomes) in homogenates of the lungs was increased 22-27 times in the lungs and 12-15 times in the heart and brain (compare bars 1 and 2, hypoxia, in Fig. 7). Similar to the expression of pro-apoptotic caspase 9 protein, empty liposomes did not influence significantly on the level of apoptosis in all organs in normoxia and hypoxia (Fig. 7 (bars 2 and 3)). In contrast, ASO or siRNA delivered by liposomes into the cells after their systemic administration significantly limited hypoxic activation of cell death in the lungs and brain (Fig. 7 (bars 4 and 5, hypoxia)).

As an example of tissue histological changes, lung tissues of mice exposed to $6 \%$ oxygen for $2 \mathrm{~h}$ were used. 


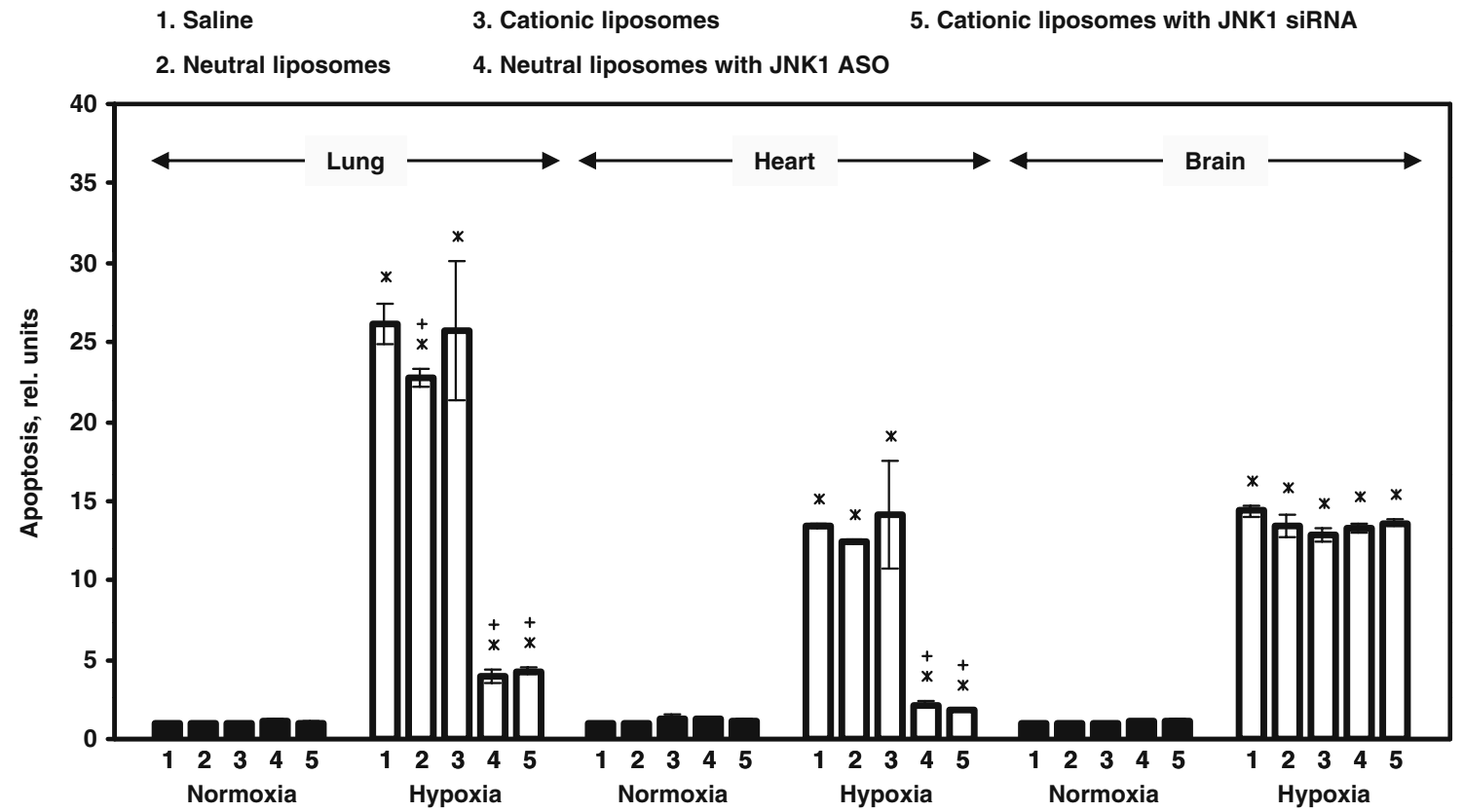

Fig. 7 Apoptosis intensity in different organs of mice during normoxia and hypoxia. Hypoxia was induced in mice by the inhalation of gas mixture containing $6 \% \mathrm{O}_{2}$ for $2 \mathrm{~h}$. Control mice (normoxia) breathed room air $\left(21 \% \mathrm{O}_{2}\right)$ in the same chamber as

Hematoxylin-eosin stain of lung tissue under normoxia and hypoxia showed that hypoxia led to the serious lung injury. In addition to apoptosis, hypoxia caused necrotic cell death. As shown in the bottom panel of Fig. 8, lung tissue edema animals with hypoxia. Mice were treated with indicated substances immediately before the exposure. Means \pm SD are shown. ${ }^{*} P<0.05$ when compared with normoxia. $+P<0.05$ when compared with hypoxic mice treated with saline

is observed under hypoxia (no treatment). In mice treated with liposomal ASO and siRNA targeted to JNK1 mRNA, necrotic damage and edema produced by hypoxia were significantly less pronounced. In correlation with the organ

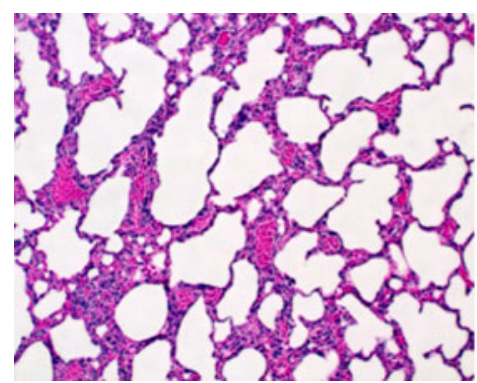

Normoxia + saline

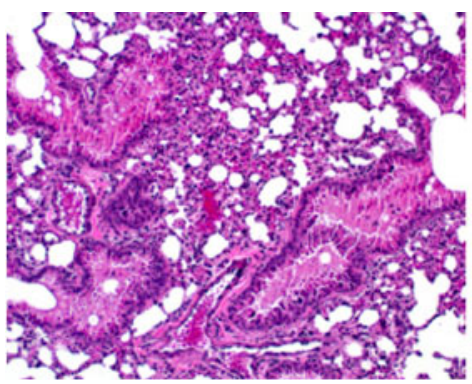

Hypoxia + saline

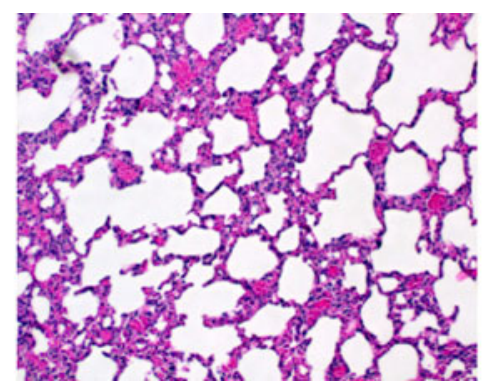

Normoxia + neutral liposomes with JNK1 ASO

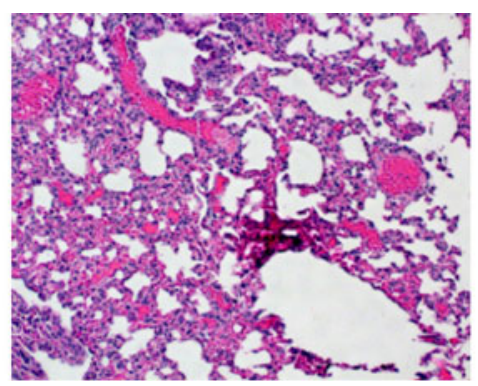

Hypoxia + neutral liposomes with JNK1 ASO

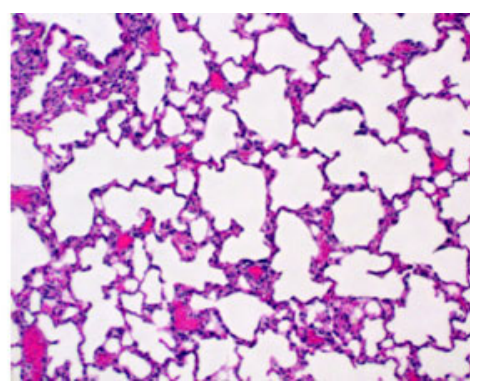

Normoxia + cationic liposomes with JNK1 siRNA

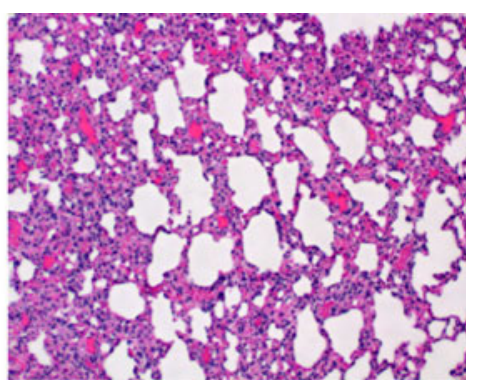

Hypoxia + cationic liposomes with JNK1 siRNA
Fig. 8 Typical light microscopy images of lung tissue sections stained with hematoxylin-eosin. Hypoxia was induced in mice by the inhalation of gas mixture containing $6 \% \mathrm{O}_{2}$ for $2 \mathrm{~h}$. Control mice (normoxia) breathed room air $\left(21 \% \mathrm{O}_{2}\right)$ in the same chamber as animals with hypoxia. Mice were treated with saline and indicated substances immediately before the exposure 
distribution of liposomal ASO and siRNA, treatment of mice breathing hypoxic gas mixture with liposomes containing ASO or complexated with siRNA did not influence the hypoxic tissue and cellular damage in the brain (Figs. 4, 5, 6, and 7).

\section{Discussion}

Based on the analysis of literature data (Bennett et al. 2001; Zhou et al. 2004) and our previously reported in vitro results (Betigeri et al. 2006), we hypothesized that suppression of JNK1 protein will limit cell death and tissue damage induced by severe hypoxia. To verify our hypothesis, we carried out experiments on mice exposed to exogenous hypoxia caused by inhalation of gas mixture containing $6 \%$ oxygen. In order to suppress JNK1 protein, we used neutral liposomes containing P-ethoxy-modified electrically neutral ASO and cationic liposomes complexed with siRNA. ASO and siRNA were designed to suppress JNK protein expression. The liposomes containing active payload were intravenously injected into the tail vein of the mice before hypoxic exposure. Control mice received saline or empty liposomes of both types. As expected, breathing a gas mixture containing $6 \% \mathrm{O}_{2}$ within $2 \mathrm{~h}$ induced severe hypoxia associated with lactic acid accumulation in all studied organs. This tissue hypoxia induced caspasedependent cell death signaling pathway and led to substantial apoptosis induction and tissue damage. After systemic administration, ASO or siRNA delivered by liposomes accumulated in all studied organs excluding the brain. This led to the suppression of targeted JNK1 protein, break down of the cell death signal, limited apoptosis, necrosis and tissue damage under hypoxic exposure. The observed suppression of cell death was evident only in organs with substantial accumulation of liposomal ASO or siRNA, which confirmed that the inhibition of targeted protein following hypoxic cellular damage was caused by ASO or siRNA targeted to JNK1 mRNA delivered by liposomes. Consequently, the defensive action of the treatment was associated with the direct local suppression of targeted JNK1 protein but not with other systemic effects. Therefore, we were able to verify the hypothesis and provide proof of concept of a unique approach to the prevention of cellular damage under severe hypoxia by the suppression of JNK1 hypoxic pathways.

Other approaches can be potentially used separately or in combination with the suppression of JNK1 to limit or prevent tissue damage during hypoxia (Minko et al. 2005). Previously we have shown that antioxidant $\alpha$-tocopherol delivered by liposomes significantly limited hypoxic damage under lung edema (Minko et al. 2002). Liposomal antioxidant agents were also successfully used to protect organs from ischemic damage (Rivera et al. 2008; Sinha et al. 2001). In addition, gene delivery into ischemic myocardium by double-targeted lipoplexes with anti-myosin antibody and TAT peptide was tested (Ko et al. 2009). Therefore, the combination of gene and antioxidant therapy has high potential in treatment of hypoxic tissue damage.

The experimental data clearly showed the correlation between the accumulation of delivered ASO or siRNA in organs and anti-hypoxic effect of the treatment. In fact, relatively high accumulation of liposomes and their payload in the lungs and heart substantially limited cell death induction in these organs. In contrast, a trace amount of liposomes, ASO and siRNA accumulated in the brain after systemic administration and was not able to prevent hypoxic brain tissue damage. Therefore, a different strategy and thus a special approach to the delivery through the blood-brain barrier should be used in order to prevent the damage to the brain during severe hypoxia. Conjugation of liposomes with TAT peptide (Gupta et al. 2007; MacKay et al. 2008; Rapoport and Lorberboum-Galski 2009) or transferrin (Soni et al. 2008) potentially can be used in order to accomplish the penetration of liposomes via the blood-brain barrier and delivery of drugs and other active components to the brain.

Acknowledgments This work was supported in part by CA111766 and CA100098 NIH grants.

Open Access This article is distributed under the terms of the Creative Commons Attribution Noncommercial License which permits any noncommercial use, distribution, and reproduction in any medium, provided the original author(s) and source are credited.

\section{References}

Bennett BL, Sasaki DT, Murray BW, O'Leary EC, Sakata ST, Xu W, Leisten JC, Motiwala A, Pierce S, Satoh Y, Bhagwat SS, Manning AM, Anderson DW (2001) SP600125, an anthrapyrazolone inhibitor of Jun N-terminal kinase. Proc Natl Acad Sci USA 98:13681-13686

Betigeri S, Pakunlu RI, Wang Y, Khandare JJ, Minko T (2006) JNK1 as a molecular target to limit cellular mortality under hypoxia. Mol Pharm 3:424-430

Blokhina O, Fagerstedt KV (2010) Oxidative metabolism, ROS and NO under oxygen deprivation. Plant Physiol Biochem 48:359-373

Boning D, Rojas J, Serrato M, Reyes O, Coy L, Mora M (2008) Extracellular $\mathrm{pH}$ defense against lactic acid in untrained and trained altitude residents. Eur J Appl Physiol 103:127-137

Busl KM, Greer DM (2010) Hypoxic-ischemic brain injury: pathophysiology, neuropathology and mechanisms. NeuroRehabilitation 26:5-13

Carlsson Y, Leverin AL, Hedtjarn M, Wang X, Mallard C, Hagberg H (2009) Role of mixed lineage kinase inhibition in neonatal hypoxia-ischemia. Dev Neurosci 31:420-426

Chihab R, Ferry C, Koziel V, Monin P, Daval JL (1998) Sequential activation of activator protein-1-related transcription factors and JNK protein kinases may contribute to apoptotic death induced 
by transient hypoxia in developing brain neurons. Brain Res Mol Brain Res 63:105-120

Cho DH, Lee HJ, Kim HJ, Hong SH, Pyo JO, Cho C, Jung YK (2007a) Suppression of hypoxic cell death by APIP-induced sustained activation of AKT and ERK1/2. Oncogene 26:2809-2814

Cho YE, Ko JH, Kim YJ, Yim JH, Kim SM, Park JH (2007b) mHGTD-P mediates hypoxic neuronal cell death via the release of apoptosis-inducing factor. Neurosci Lett 416:144-149

Corbucci GG, Marchi A, Lettieri B, Luongo C (2005) Mechanisms of cell protection by adaptation to chronic and acute hypoxia: molecular biology and clinical practice. Minerva Anestesiol 71: $727-740$

Crenesse D, Laurens M, Heurteaux C, Cursio R, Saint-Paul MC, Schmid-Alliana A, Gugenheim J (2003) Rat liver ischemiareperfusion-induced apoptosis and necrosis are decreased by FK506 pretreatment. Eur J Pharmacol 473:177-184

Danielyan L, Buniatian GH, Gleiter CH (2006) Common neuroprotective effects of endothelin receptor a blockade and erythropoietin during hypoxia-associated cell injury. Perspectives of combined treatment. Scientific World Journal 6:449-451

Derijard B, Hibi M, Wu IH, Barrett T, Su B, Deng T, Karin M, Davis RJ (1994) JNK1: a protein kinase stimulated by UV light and HaRas that binds and phosphorylates the c-Jun activation domain. Cell 76:1025-1037

Dhar-Mascareno M, Carcamo JM, Golde DW (2005) Hypoxiareoxygenation-induced mitochondrial damage and apoptosis in human endothelial cells are inhibited by vitamin C. Free Radic Biol Med 38:1311-1322

Dharap SS, Wang Y, Chandna P, Khandare JJ, Qiu B, Gunaseelan S, Sinko PJ, Stein S, Farmanfarmaian A, Minko T (2005) Tumorspecific targeting of an anticancer drug delivery system by LHRH peptide. Proc Natl Acad Sci USA 102:12962-12967

Freiberg RA, Krieg AJ, Giaccia AJ, Hammond EM (2006) Checking in on hypoxia/reoxygenation. Cell Cycle 5:1304-1307

Garay M, Gaarde W, Monia BP, Nero P, Cioffi CL (2000) Inhibition of hypoxia/reoxygenation-induced apoptosis by an antisense oligonucleotide targeted to JNK1 in human kidney cells. Biochem Pharmacol 59:1033-1043

Garbuzenko OB, Saad M, Betigeri S, Zhang M, Vetcher AA, Soldatenkov VA, Reimer DC, Pozharov VP, Minko T (2009) Intratracheal versus intravenous liposomal delivery of siRNA, antisense oligonucleotides and anticancer drug. Pharm Res 26:382-394

Garbuzenko OB, Saad M, Pozharov VP, Reuhl KR, Mainelis G, Minko T (2010) Inhibition of lung tumor growth by complex pulmonary delivery of drugs with oligonucleotides as suppressors of cellular resistance. Proc Natl Acad Sci USA 107:10737-10742

Gonchar O, Mankovskaya I (2009) Effect of moderate hypoxia/ reoxygenation on mitochondrial adaptation to acute severe hypoxia. Acta Biol Hung 60:185-194

Goni-de-Cerio F, Alvarez A, Caballero A, Mielgo VE, Alvarez FJ, Rey-Santano MC, Gastiasoro E, Valls-i-Soler A, Bilbao J, Hilario E (2007) Early cell death in the brain of fetal preterm lambs after hypoxic-ischemic injury. Brain Res 1151:161-171

Gupta B, Levchenko TS, Torchilin VP (2007) TAT peptide-modified liposomes provide enhanced gene delivery to intracranial human brain tumor xenografts in nude mice. Oncol Res 16:351-359

Hellwig-Burgel T, Stiehl DP, Wagner AE, Metzen E, Jelkmann W (2005) Review: hypoxia-inducible factor-1 (HIF-1): a novel transcription factor in immune reactions. J Interferon Cytokine Res 25:297-310

Hossain MA (2008) Hypoxic-ischemic injury in neonatal brain: involvement of a novel neuronal molecule in neuronal cell death and potential target for neuroprotection. Int $\mathrm{J}$ Dev Neurosci 26:93-101

Hreniuk D, Garay M, Gaarde W, Monia BP, McKay RA, Cioffi CL (2001) Inhibition of c-Jun N-terminal kinase 1, but not c-Jun N- terminal kinase 2, suppresses apoptosis induced by ischemia/ reoxygenation in rat cardiac myocytes. Mol Pharmacol 59:867-874

Hung TH, Burton GJ (2006) Hypoxia and reoxygenation: a possible mechanism for placental oxidative stress in preeclampsia. Taiwan J Obstet Gynecol 45:189-200

Karin M (1995) The regulation of AP-1 activity by mitogen-activated protein kinases. J Biol Chem 270:16483-16486

Kim BM, Choi JY, Kim YJ, Woo HD, Chung HW (2007) Reoxygenation following hypoxia activates DNA-damage checkpoint signaling pathways that suppress cell-cycle progression in cultured human lymphocytes. FEBS Lett 581:3005-3012

Kim JY, Ahn HJ, Ryu JH, Suk K, Park JH (2004) BH3-only protein Noxa is a mediator of hypoxic cell death induced by hypoxiainducible factor 1alpha. J Exp Med 199:113-124

Kim JY, Park JH (2003) ROS-dependent caspase-9 activation in hypoxic cell death. FEBS Lett 549:94-98

Ko YT, Hartner WC, Kale A, Torchilin VP (2009) Gene delivery into ischemic myocardium by double-targeted lipoplexes with antimyosin antibody and TAT peptide. Gene Ther 16:52-59

Kothari S, Cizeau J, McMillan-Ward E, Israels SJ, Bailes M, Ens K, Kirshenbaum LA, Gibson SB (2003) BNIP3 plays a role in hypoxic cell death in human epithelial cells that is inhibited by growth factors EGF and IGF. Oncogene 22:4734-4744

Lecour S, Van der Merwe E, Opie LH, Sack MN (2006) Ceramide attenuates hypoxic cell death via reactive oxygen species signaling. J Cardiovasc Pharmacol 47:158-163

MacKay JA, Li W, Huang Z, Dy EE, Huynh G, Tihan T, Collins R, Deen DF, Szoka FC Jr (2008) HIV TAT peptide modifies the distribution of DNA nanolipoparticles following convectionenhanced delivery. Mol Ther 16:893-900

Meerson F, Pozharov V, Minyailenko T (1994) Superresistance against hypoxia after preliminary adaptation to repeated stress. J Appl Physiol 76:1856-1861

Millet GP, Roels B, Schmitt L, Woorons X, Richalet JP (2010) Combining hypoxic methods for peak performance. Sports Med 40:1-25

Minciu Macrea M, Misra H, Zagrean L (2010) The neuroprotective effect of intranasally applied leptin against hypoxic neuronal injury. Med Hypotheses 74:1036-1037

Minko T, Kopeckova P, Kopecek J (1999) Comparison of the anticancer effect of free and HPMA copolymer-bound adriamycin in human ovarian carcinoma cells. Pharm Res 16:986-996

Minko T, Stefanov A, Pozharov V (2002) Selected contribution: lung hypoxia: antioxidant and antiapoptotic effects of liposomal alphatocopherol. J Appl Physiol 93:1550-1560, discussion 1549

Minko T, Wang Y, Pozharov V (2005) Remediation of cellular hypoxic damage by pharmacological agents. Curr Pharm Des 11:3185-3199

Murray J, Walmsley SR, Mecklenburgh KI, Cowburn AS, White JF, Rossi AG, Chilvers ER (2003) Hypoxic regulation of neutrophil apoptosis role: of reactive oxygen intermediates in constitutive and tumor necrosis factor alpha-induced cell death. Ann NY Acad Sci 1010:417-425

Myllyharju J (2008) Prolyl 4-hydroxylases, key enzymes in the synthesis of collagens and regulation of the response to hypoxia, and their roles as treatment targets. Ann Med 40:402-417

Nagel S, Talbot NP, Mecinovic J, Smith TG, Buchan AM, Schofield CJ (2010) Therapeutic manipulation of the HIF hydroxylases. Antioxid Redox Signal 12:481-501

Ostadal B, Kolar F (2007) Cardiac adaptation to chronic high-altitude hypoxia: beneficial and adverse effects. Respir Physiol Neurobiol 158:224-236

Pakunlu RI, Cook TJ, Minko T (2003) Simultaneous modulation of multidrug resistance and antiapoptotic cellular defense by MDR1 and BCL-2 targeted antisense oligonucleotides enhances the anticancer efficacy of doxorubicin. Pharm Res 20:351-359

Pakunlu RI, Wang Y, Saad M, Khandare JJ, Starovoytov V, Minko T (2006) In vitro and in vivo intracellular liposomal delivery of 
antisense oligonucleotides and anticancer drug. J Control Release 114:153-162

Pakunlu RI, Wang Y, Tsao W, Pozharov V, Cook TJ, Minko T (2004) Enhancement of the efficacy of chemotherapy for lung cancer by simultaneous suppression of multidrug resistance and antiapoptotic cellular defense: novel multicomponent delivery system. Cancer Res 64:6214-6224

Patil ML, Zhang M, Betigeri S, Taratula O, He H, Minko T (2008) Surface-modified and internally cationic polyamidoamine dendrimers for efficient siRNA delivery. Bioconjug Chem 19:13961403

Portugal-Cohen M, Kohen R (2009) Exposure of human keratinocytes to ischemia, hyperglycemia and their combination induces oxidative stress via the enzymes inducible nitric oxide synthase and xanthine oxidase. J Dermatol Sci 55:82-90

Rapoport M, Lorberboum-Galski H (2009) TAT-based drug delivery system-new directions in protein delivery for new hopes? Expert Opin Drug Deliv 6:453-463

Ricci L, Valoti M, Sgaragli G, Frosini M (2009) Protection by taurine of rat brain cortical slices against oxygen glucose deprivationand reoxygenation-induced damage. Eur J Pharmacol 621:26-32

Rivera F, Costa G, Abin A, Urbanavicius J, Arruti C, Casanova G, Dajas F (2008) Reduction of ischemic brain damage and increase of glutathione by a liposomal preparation of quercetin in permanent focal ischemia in rats. Neurotox Res 13:105-114

Sinha J, Das N, Basu MK (2001) Liposomal antioxidants in combating ischemia-reperfusion injury in rat brain. Biomed Pharmacother 55:264-271

Soleymanlou N, Jurisicova A, Wu Y, Chijiiwa M, Ray JE, Detmar J, Todros T, Zamudio S, Post M, Caniggia I (2007) Hypoxic switch in mitochondrial myeloid cell leukemia factor-1/Mtd apoptotic rheostat contributes to human trophoblast cell death in preeclampsia. Am J Pathol 171:496-506

Soni V, Kohli DV, Jain SK (2008) Transferrin-conjugated liposomal system for improved delivery of 5-fluorouracil to brain. J Drug Target 16:73-78
Surova OV, Nagibin VS, Tumanovskaya LV, Dosenko VE, Moibenko AA (2009) Effect of a low dose of proteasome inhibitor on cell death and gene expression in neonatal rat cardiomyocyte cultures exposed to anoxia-reoxygenation. Exp Clin Cardiol 14:e57-e61

Vacotto M, Coso O, Fiszer de Plazas S (2008) Programmed cell death and differential JNK, p38 and ERK response in a prenatal acute hypoxic hypoxia model. Neurochem Int 52:857-863

Wang Y, Minko T (2004) A novel cancer therapy: combined liposomal hypoxia inducible factor 1 alpha antisense oligonucleotides and an anticancer drug. Biochem Pharmacol 68:2031-2042

Wang Y, Pakunlu RI, Tsao W, Pozharov V, Minko T (2004) Bimodal effect of hypoxia in cancer: the role of hypoxia inducible factor in apoptosis. Mol Pharm 1:156-165

Wang Y, Saad M, Pakunlu RI, Khandare JJ, Garbuzenko OB, Vetcher AA, Soldatenkov VA, Pozharov VP, Minko T (2008) Nonviral nanoscale-based delivery of antisense oligonucleotides targeted to hypoxia-inducible factor 1 alpha\} enhances the efficacy of chemotherapy in drug-resistant tumor. Clin Cancer Res 14:3607-3616

Wenger RH, Camenisch G, Stiehl DP, Katschinski DM (2009) HIF prolyl-4-hydroxylase interacting proteins: consequences for drug targeting. Curr Pharm Des 15:3886-3894

Yajima D, Motani H, Hayakawa M, Sato Y, Sato K, Iwase H (2009) The relationship between cell membrane damage and lipid peroxidation under the condition of hypoxia-reoxygenation: analysis of the mechanism using antioxidants and electron transport inhibitors. Cell Biochem Funct 27:338-343

Zhao Y, Chen XQ, Du JZ (2009) Cellular adaptation to hypoxia and p53 transcription regulation. J Zhejiang Univ Sci B 10:404-410

Zhou G, Golden T, Aragon IV, Honkanen RE (2004) Ser/Thr protein phosphatase 5 inactivates hypoxia-induced activation of an apoptosis signal-regulating kinase $1 / \mathrm{MKK}-4 / \mathrm{JNK}$ signaling cascade. J Biol Chem 279:46595-46605

Zhu H, Wang WJ, Ding WL, Li F, He J (2008) Effect of panaxydol on hypoxia-induced cell death and expression and secretion of neurotrophic factors (NTFs) in hypoxic primary cultured Schwann cells. Chem Biol Interact 174:44-50 